\title{
Ocular transient receptor potential channel function in health and disease
}

\author{
Peter S. Reinach ${ }^{1 *}$, Stefan Mergler ${ }^{2}$, Yuka Okada $^{3}$ and Shizuya Saika ${ }^{3}$
}

\begin{abstract}
Transient receptor potential (TRP) channels sense and transduce environmental stimuli into $\mathrm{Ca}^{2+}$ transients that in turn induce responses essential for cell function and adaptation. These non-selective channels with variable $\mathrm{Ca}^{2+}$ selectivity are grouped into seven different subfamilies containing 28 subtypes based on differences in amino acid sequence homology. Many of these subtypes are expressed in the eye on both neuronal and non-neuronal cells where they affect a host of stress-induced regulatory responses essential for normal vision maintenance. This article reviews our current knowledge about the expression, function and regulation of TRPs in different eye tissues. We also describe how under certain conditions TRP activation can induce responses that are maladaptive to ocular function. Furthermore, the possibility of an association between TRP mutations and disease is considered. These findings contribute to evidence suggesting that drug targeting TRP channels may be of therapeutic benefit in a clinical setting. We point out issues that must be more extensively addressed before it will be possible to decide with certainty that this is a realistic endeavor. Another possible upshot of future studies is that disease process progression can be better evaluated by profiling changes in tissue specific functional TRP subtype activity as well as their gene and protein expression.
\end{abstract}

Keywords: Transient receptor potential ion channels, Calcium, Retina, Cornea, Uvea, Lens

\section{TRP channel characteristics}

In 1969, a Drosophila mutant was identified having defective vision (abnormal electroretinogram) in which light-induced channel activation elicited a transient rather than sustained membrane voltage depolarization [1-3]. About 20 years later, this aberrant behavior was attributed to a mutant TRP gene. Subsequent to its cloning in 1989 it was realized that a mutation in the trp gene underlay this aberrant light response. Specifically, cloning and sequencing of the Drosophila trp gene showed that its 4.1-kb RNA transcript encodes a 1275-amino acid protein $[1,4]$. Since extracellular application of the non-specific $\mathrm{Ca}^{2+}$ channel blocker lanthanum-III-chloride $\left(\mathrm{La}^{3+}\right)$ to the retina of the blowfly Calliphora caused extreme weakening of the receptor potential to the dark baseline level during a light pulse [1]. This response showed that trp is a light sensitive channel. This breakthrough led to the realization that

\footnotetext{
* Correspondence: preinach@yahoo.com

${ }^{1}$ Department of Ophthalmology and Optometry, Wenzhou Medical

University, 270 Xuejuan Road, Wenzhou, Zhejiang 325027, P. R. China

Full list of author information is available at the end of the article
}

other channels with unique structures had nevertheless a signature TRP sequence (i.e. TRP box).

These TRP box containing channels are characteristic of a superfamily in mammals derived from 28 different genes. They are further categorized by separating them into six different subfamilies based on their sensitivity to activation by different stimuli. TRP receptor channel activation in different ocular tissues is essential for not only visual processing, but also the maintenance of normal health. These non-selective channels transduce environmental stresses into cell signaling events controlling different adaptive responses needed for offsetting such challenges. Emerging indications of their importance has prompted efforts to identify lead compounds, which can modulate their activation profiles in order to counter losses in cellular function caused by tissue injury, touch, fluctuations in ambient temperature, $\mathrm{pH}$ as well as medium osmolarity, hormonal exposure and pathogen infiltration. This endeavor can lead to the development of novel strategies for improving the treatment of different ocular diseases in a clinical setting. 
TRPs are non-selective cation channels with variable $\mathrm{Ca}^{2+}$ permselectivity. Their activation by a vast array of different stimuli elicits intracellular $\mathrm{Ca}^{2}$ transients leading to downstream stimulation of various signaling pathways as well as in some cases transactivating other receptor types. It is still unclear how TRP responses encode through modulation of $\mathrm{Ca}^{2+}$ influx a myriad of downstream signaling events triggering response formation [5-7].

We review here TRP functional involvement in cornea, conjunctival epithelium, uvea, lens and retina. It is our intent that the reader will a) more fully appreciate their importance in maintaining ocular function; b) realize that changes in TRP functional expression can underlie ocular disease.

\section{TRP channel channelopathies and nomenclature}

TRPs sense diverse environmental stimuli including ambient temperature, changes in membrane stress, declines in $\mathrm{pH}$, exposure to anisosmotic media and environmental ligands as well as kinase-induced channel phosphorylation [8-10]. Changes in their function due to mutation [so-called (TRP) channelopathies] are associated with human diseases such as cancer [6, 11-13]. There are strong indications that variant TRP expression is also involved in many diseases (e.g. mutations in TRPs are responsible for various kidney diseases), or cancer (e.g. prostate, breast, colon, rectum) [6, 14]. Structure function TRP relationship studies contribute to development of novel strategies for reversing dysfunctional responses underlying various pathological conditions.

TRPs consist of six putative transmembrane domains with a pore loop between the fifth and sixth spanning segments. The span between the fifth and sixth segments forms a conduit for cation membrane permeation. Each channel is composed of four subunits that can be organized in either a heteromeric or homomeric configuration. These different subunit combination possibilities account for $\mathrm{Ca}^{2+}$ selectivity variability. Various different subfamilies of TRPs are known [7, 15-18]. Based on amino acid sequence and functional similarities, TRP channels are divided into seven main subfamilies: a) TRPA (ankyrin); b) TRPC 1-4 (canonical); c) TRPM1-8 (melastatin) [19, 20]. TRPM8 (originally named Trp-p8) is a cold- and menthol-sensing $\mathrm{Ca}^{2+}$-permeable channel which plays a crucial role in cold thermosensation; Except for TRPM4 and TRPM5, all other TRPs are permeable to $\mathrm{Ca}^{2+}[12,21]$. d) TRPML (mucolipin); e) TRPN (no mechano potential); f) TRPP (polycystin: g) TRPV1-7 (vanilloid) [5, 22]. Drosophila phototransduction is mediated by a TRPC channel together with a second TRPC channel trp-like (TRPL) [23, 24].

\section{Impact of altered TRP expression on cellular functions and disease states}

Modulation of TRP channel activity contributes to the control of cell growth, differentiation, proliferation or secretion through changes in intracellular $\mathrm{Ca}^{2+}$ levels. This can trigger downstream linked signaling pathways controlling gene expression events underlying each of these responses. On the other hand, aberrant enhanced TRP channel activation leading to non-physiological rises in extracellular calcium influx or intracellular calcium release from stores (e.g. endoplasmic reticulum) by $\mathrm{Ca}^{2+}$-release channels (e.g. $\mathrm{IP}_{3}$, ryanodine receptors) can induce apoptosis in various cell types. For example, Yoon et al. found that there is an extremely rapid photoreceptor cell death when a TRP channel is constitutively active due to mutations [25]. In the corneal endothelium, changes in TRP channel activity affect its role in maintaining tissue transparency (barrier and pump function) [26]. On the other hand, calcium overload caused by growth factor-induced TRP channel activation can lead to calcium overload and excessive apoptosis [27, 28]. Such a change can as well compromise organ transplantation success and pathogenesis of eye diseases (e.g. corneal dystrophy) and may contribute to donor cornea shortage [29].

\section{Determinants of TRP thermosensitivity}

Out of the 28 mammalian TRP genes, 6 different thermosensitive TRP isotypes are expressed in the eye. They include TRPV1, 2, 3 and 4 as well as TRPM8 and TRPA1 whose temperature sensitivities cover most of the environmental conditions that mammals encounter. TRPV4 and TRPV3 are activated by temperatures from 25 to $31{ }^{\circ} \mathrm{C}$, respectively, whereas TRPV1 is activated at $43{ }^{\circ} \mathrm{C}$ and TRPV2 at a noxious temperature of $51{ }^{\circ} \mathrm{C}$ [30]. TRPM 8 and TRPA1 on the other hand sense cooling once the temperature drops below 25 and $17{ }^{\circ} \mathrm{C}$, respectively. It is unclear whether one of these three suggested mechanisms can account for the origin of the remarkably steep temperature sensitivity of the thermosensitive TRPs (thermo-TRPs). They include: 1) steep specific temperature dependence for ligand binding; 2) temperature-induced channel rearrangement; 3) temperature-dependent membrane tension changes controlling channel opening [31]. A definitive explanation for why only certain TRPs are thermosensitive remains somewhat elusive. Nevertheless, a recent report suggests that there are specific TRP channel molecular determinants endowing thermal sensitivity. In Drosophila, different TRPA1 isoforms are expressed and the requirement for TRPA1 thermal sensitivity was linked to the expression of a specific 37-aminoacid sequence within its intracellular region (encoded by a single exon) [32]. 
Cataloging which TRP subtypes elicit specific responses can be problematic if the characterization is based solely on drug-induced effects. This limitation stems from the fact that their effects are not restricted to interacting with a single subtype. Accordingly, transgenic animals are used to assess the impact of either a gain or loss of TRP function on an induced response. Even such a precaution may be confounded by compensatory upregulation of another gene replacing the functional loss resulting from a deleted gene. Despite these possible caveats, current assignments of functional roles of TRP channel subtypes appear to be accurate.

\section{Classical activation mechanism}

Initially, it was realized that either exogenous small organic synthetic compounds or natural products can activate TRPs. Besides capsaicin, [33] other (synthetic) agonists are icilin (TRPM8) [34] and camphor (TRPV3) $[35,36]$ which are super cooling agents. Furthermore, endogenous lipids or products of lipid metabolism are also ligands of TRPs. For example, anandamide is an endogenous lipid [37]. Inorganic ions such as $\mathrm{Ca}^{2+}$ or $\mathrm{Mg}^{2+}$ can also (directly) activate TRPs (e.g. TRPM6 for $\mathrm{Mg}^{2+}$ ) [38] (e.g. TRPA1 for $\mathrm{Ca}^{2+}$ ) [39]. However, it is not yet known if the TRP conformational changes induced by $\mathrm{Ca}^{2+}$ or $\mathrm{Mg}^{2+}$ are the same as those induced by a thermal transition known to activate these different TRP channel subtypes. Overall, classical activation of TRPs and in particular thermo-TRPs are mostly related to direct activation via mechanical stimuli, channel phosphorylation, certain exogenous and endogenous agents or inorganic ions.

\section{TRP channel regulation by $\mathrm{G}$ protein-coupled receptors}

Studies in Drosophila photoreceptors by Devary et al. demonstrated for the first time that the light activated TRP channels and TRPL are targets of G proteincoupled receptor (GPCR) activated rhodopsin, which lead to activation of Gq, PLC and $\mathrm{PIP}_{2}$ hydrolysis [40]. Another study by Hardie et al. showed for the first time that the DAG branch of PI-signaling (and PUFAs) also activates in Drosophila TRP and TRPL channels [23]. Therefore, TRPs can also be (indirectly) activated by GPCRs and receptor tyrosine kinases (RTKs) activating phospholipase C (PLC). This can occur in different ways such as generation of inositol $(1,4,5)$ trisphosphate $\left(\mathrm{IP}_{3}\right)$ and subsequent $\mathrm{Ca}^{2+}$ release from intracellular stores, which in turn activates store-operated $\mathrm{Ca}^{2+}$ channels (SOCs) composed of TRP subunits such as TRPC1 and TRPC4 [41]. Another way which GPCRs can modulate TRP channel activity is via the generation of diacylglycerol (DAG) (e.g. diacylglycerol-sensitive TRPC3/6/7) [42]. Finally, GPCRs can modulate TRPs via hydrolysis of phosphatidylinositol $(4,5)$ bisphosphate $\left(\mathrm{PIP}_{2}\right)$ (TRPM8) [43] (TRPC4) [44].

\section{TRPs in ocular tissues and cells}

Uvea, retina and retinal pigment epithelium

Besides the TRP channel subtypes mediating retinal phototransduction in the Drosophila eye $[1,2,45,46]$, other subtypes identified in the mouse retina include: TRPC1-4 TRPM1/3/7, TRPML1, TRPP2, TRPV2, TRPV4 $[47,48]$. In mouse retinal ganglion cells (RGCs), TRPV4 modulates calcium flux, spiking rate, and apoptosis of these cells [48]. TRPV1 in rat retina contributes to eliciting RGC apoptosis and increased intracellular $\mathrm{Ca}^{2+}$ levels during exposure to elevated hydrostatic pressure [49]. Furthermore, TRPC1 and TRPC4 are expressed in chicken retina [50]. In the human retina, TRPM1 expression was detected on ON-bipolar cell dendrites. This suggests a dual function for TRPM1 in the ON-pathway [51]. More specifically, TRPM1 is required for the photoresponse in mouse retinal ON-bipolar cells and it is regulated by the metabotropic glutamate receptor 6 (mGulR6) cascade in ON-bipolar cells [52-56]. Many human mutations affected this system [53]. Other TRPs like TRPV1, TRPM8 and TRPA1 are expressed in retinal tumor cells (retinoblastoma). On the other hand, TRPA1 is completely suppressed in a retinoblastoma cell line, which is resistant to the cytostatic agent etoposide [57]. In addition, TRPV1-4, TRPM8 and TRPA1 were identified in retinal pigment epithelial (RPE) cells $[58,59]$. Increasing the ambient temperature or insulin like growth factor-1 (IGF-1) enhanced vascular endothelial growth factor-A (VEGF-A) secretion rate in RPE cells [58]. TRPs are involved in the IGF-1 induced response [58]. Regarding the human uvea, there is only one study demonstrating gene expression of TRPV1, TRPM8 and TRPA1 [59]. In contrast, in human uveal melanoma cells, the gene expression of TRPM8 is at lower levels whereas the TRPA1 expression is at high levels in healthy uvea [59].

\section{Corneal epithelium}

TRPC4 is the first TRP channel subtype identified in human corneal epithelial cells (HCEC). Activation by epidermal growth factor of its cognate receptor, EGFR, transactivates TRPC4. The resulting increases in intracellular trigger mitogen activated protein kinase (MAPK) cascade signaling leading to rises in cell proliferation and migration in vitro and in vivo [60]. Conversely, TRPV1 activation by capsaicin, induces increases in cell proliferation and migration through mediating increases in release of heparin bound EGF, which transactivates EGFR [61]. TRPV1-4 vanilloid are expressed in rat, mice and HCEC [62-64]. Thermal transitions were used to delineate functional TRPV1-4, [65-72] and TRPM8/ TRPA1 [73, 74] expression. 
TRPV1 expression in HCEC has potential clinical relevance since in TRPV1 knockout mice re-epithelialization and restoration of tissue transparency following debridement was delayed in these mice compared to their wild type counterpart. This effect of TRPV1 in promoting cell proliferation and migration is associated with increases in IL-6 and substance P expression, which are coactivators of growth factor induced wound healing [62]. TRPV4 expression in intact human corneal epithelium and its activation by exposure to a hypotonic challenge is required for inducing regulatory cell volume decrease behavior [75]. Furthermore, Pan et al. [76] found that hypertonic stresses identical to those described in some dry eye patient tears elicited TRPV1 channel stimulation leading to rises in proinflammatory cytokine levels through MAPK and NF-kB activation [64, 77]. TRPM8 cold receptor gene, protein and functional expression was detected in HCEC. On the other hand, TRPM8 activation by either temperature lowering or icilin inhibits TRPV1-induced increases in intracellular $\mathrm{Ca}^{2+}$ levels (Türker, Mergler et al. unpublished observation 2015).

\section{Corneal stroma}

Functional TRPV1 expression was identified in human stromal fibroblast cultures [78, 79]. Transforming growth factor TGF $\beta-1$ transactivates TRPV1 in these cultures through activation of its cognate receptor, TGF $\beta$ R. In vivo, a murine corneal alkali burn compromises basement membrane integrity leading to TGF $\beta$ stromal infiltration and myofibroblast transdifferentiation, fibrosis and a proinflammatory cytokine, chemoattractant storm followed by immune cell infiltration. These injury-induced effects cause corneal opacification and ulceration [80]. This marked difference in the wound healing outcome resulting from epithelial and stromal TRPV1 activation suggests that TRPV1 antagonist usage in a clinical setting may need to be restricted to cases involving penetrating stromal injury rather than superficial epithelial injury. TRPM8 gene, protein and functional expression was validated in human corneal stromal cells (Türker, Mergler et al. unpublished observation 2015).

\section{Corneal nerve fibers}

Thermosensitive TRPA1 and TRPM8 are also expressed on corneal afferent nerves [81]. Corneal nerve fibers are radially distributed within the stroma and the adjacent limbus [82]. TRPV1 and TRPM8 are highly expressed in mouse, guinea pig and human corneal sensory nerve fibers at levels similar to those in their non-corneal counterpart [81, 83-85] and in non-corneal primary sensory neurons [30]. These channels desensitize during prolonged exposure to capsaicin (TRPV1) or menthol (TRPM8). In a clinical setting, nerve fiber TRPM8 activation by a super cooling agent may provide an option for treating dry eye syndrome since corneal cooling in humans increased lacrimation, whereas warming had an opposite effect [81]. Parra et al. found that TRPM8 functional expression is needed to maintain ocular surface hydration during exposure to a desiccating stress [81]. Taken together, these results suggest that drug-induced fibroblast TRPV1 and neuronal TRPM8 functional modulation may provide novel options to lessen corneal opacification and increase lacrimation subsequent to a penetrating corneal injury and in aqueous deficient dry eye disease, respectively.

\section{Corneal endothelium}

Rae and Watsky [86] described in the corneal endothelium an outwardly rectifying thermosensitive current along with a $\mathrm{K}^{+}$-selective current. The origin of the thermosensitive component was not identified, but may be attributable to TRP activity [86]. More recently, thermosensitive TRPV1-4 channel activity was identified in human corneal endothelial cells $[87,88]$. Besides voltageoperated $\mathrm{Ca}^{2+}$ channels (VOCCs) $[27,28]$, there is functional menthol receptor TRPM8 expression in human corneal endothelial cells because the super cooling TRPM8 agonist icilin [34] reversibly increased intracellular $\mathrm{Ca}^{2+}$ levels [89]. Besides TRPM8 expression in human corneal endothelial cells, Mergler et al. [28] suggested that other TRP subtypes may be also expressed in human corneal endothelium since $\mathrm{H}_{2} \mathrm{O}_{2}$ induced significant rises in $\left[\mathrm{Ca}^{2+}\right]_{\mathrm{I}}$ levels. This $\mathrm{Ca}^{2+}$ rise could be due to activation of redox sensitive TRP subtypes mediating previously unexplained biological phenomena and are involved in various pathologies [90]. Corneal endothelial functional TRPM8 expression may help explain why storing isolated corneas in an eye bank setting at temperatures below those in-situ results in less swelling than at $37{ }^{\circ} \mathrm{C}$ $[89,91,92]$. TRPM8 stimulation could result in graded shifts of voltage-dependent activation to more negative membrane voltages increasing the electrical driving force for intracellular $\mathrm{Ca}^{2+}$ influx [31]. TRPM8 may be also regulated by $\mathrm{G}$ protein-coupled receptors (GPCRs) since both activation of a GPCR and a nerve growth factor receptor inhibited menthol- and cold-induced TRPM8 activity in non-corneal cells [20].

\section{Lens epithelium}

Intracellular $\mathrm{Ca}^{2+}$ regulation in lens epithelial and fiber cells is critical to lens transparency maintenance since rises in its level are cataractogenic. Functional TRPM3 and TRPV1 expression was identified in human lenses [93]. TRPM3 variants are associated with cataractogenesis [93]. TRPV4 expression in porcine lens epithelium regulates hemi-channel-mediated ATP release and $\mathrm{Na}^{+}-\mathrm{K}^{+}$-ATPase activity [94]. Plasma membrane associated store operated channel (SOC) activity is modulated through changes in 
the intracellular store (ICS) $\mathrm{Ca}^{2+}$ filling status. Such feedback control of SOC activity is mediated by TRPC1 and TRPC5 subtypes whose open time is prolonged following ICS $\mathrm{Ca}^{2+}$ depletion [76].

\section{Conjuncitval epithelial cells}

In conjunctival epithelial cells, there are temperaturesensitive TRPV1, TRPV2 as well as TRPV4 channels [95]. There are indications for crosstalk between TRPV1 and TRPM8 since TRPM8 activation suppressed TRPV1induced $\mathrm{Ca}^{2+}$ increases as well as increases in proinflammatory cytokine IL-6 release [96].

\section{Adaptive roles of functional TRP expression}

TRPs make an important contribution to maintaining tissue homeostasis under a variety of environmental conditions that can be otherwise disruptive. In humans, TRPs play an important role in modulating taste sensation, eliciting responses to painful stimuli, temperature, growth factors and pheromones [97-103]. Modulation of their activity and expression can also change the effects of stressors mediating cell death [49, 102, 104]. In addition, store-operated $\mathrm{Ca}^{2+}$ channels (SOCs) can be activated via intracellular store (ICS) calcium depletion and as aforementioned by activated GPCRs or receptorlinked tyrosine kinases (RTKs). However, their dysfunction is linked with sustained increases in cytosolic $\mathrm{Ca}^{2+}$ leading to apoptosis [97-99, 101, 105].

\section{Healthy eyes}

Worldwide, the number of people needing relief from ocular dysfunction is on the rise. One of the reasons for this increase is a change in lifestyle due to reliance on video display terminals and stresses imposed by urbanization. Corneal thermosensitive TRPV1-4, TRPA1 and TRPM 8 channels in the cornea can be activated by stresses encountered in daily living and elicit responses that can contribute to ocular disturbances. In addition, 1) TRPV1 (capsaicin); 2) TRPV2/3 (camphor, laurel tree cinnamomum camphora); 3) TRPV4, bisandrographolide in Chinese herbal plant Andrographis paniculata; 4) TRPM8, menthol in green mint; 5) TRPA1, cinnamaldehyde, isothiocyanates and allicin in horseradish are selectively ligand gated [106]. An indication of the adaptive value of TRPV1 expression in the cornea is that application of capsaicin to the ocular surface elicits excruciating pain, which elicits an avoidance response to reduce tissue injury. Thermosensitive corneal TRP expression may also provide an adaptive advantage by eliciting responses that reduce disruptive noxious thermal effects on tissue homeostasis. Similar considerations are relevant to the posterior section of the eye such as retina, uvea and retinal epithelium (RPE) since in these tissues there is also thermosensitive TRP expression (e.g.
TRPV2 in RPE) [58]. On the other hand, retinal TRPV1 expression level is low compared to that in the anterior section of the eye (e.g. lens) [107]. Furthermore, the menthol receptor, TRPM8, provides essential functions including contributing to controlling basal tear fluid secretion via corneal nerve fibers [81, 83]. In addition, human corneal endothelial TRPM8 expression may provide an adaptive advantage for preserving tissue function during temperature lowering [89]. In summary, functional thermosensitive TRP activation by environmental challenges elicits essential responses that have adaptive value in preventing or reducing tissue function compromise.

\section{Eye diseases}

With the realization in the last decade of the polymodal regulatory roles of TRP channels, there is heightening interest in studying how they elicit such control. This is evident based on the ever-increasing number of reports appearing in Pub Med and their citation frequency. One of the realizations sparking such interest is that TRP gene mutations underlie numerous inherited diseases in humans including the eye [108]. TRP channelopathies were initially linked to cardiovascular, renal, skeletal and nervous system pathology [108-110]. Regarding the eye, one of them deals with mucolipidosis type IV (MLIV) and another indicates that mutant TRPM3 expression is associated with cataractogenesis and glaucoma [93]. MLIV is an autosomal recessive, neurodegenerative lysosomal storage disorder, which is due to mutations in the gene MCOLN1. MLIV is clinically characterized not only by ophthalmologic abnormalities such as corneal opacity, retinal degeneration and strabismus, but also by other non-ocular abnormalities. MCOLN1 which encodes the protein mucolipin 1 (MNL1) is a non-specific cation channel (TRPML1) (review [111]). In addition, human TRPM1 mutations are associated with congenital stationary night blindness (CSNB), whose patients lack rod function and suffer from night blindness starting in early childhood [112].

\section{Dry eye syndrome}

The options for treating dry eye syndrome (DES) are limited for the most part to providing palliative relief. With the identification of anterior segment functional TRP expression illustrated in Fig. 1, there is suggestive evidence that they are potential drug targets for improving treatment of this disease. DES or keratoconjunctivitis sicca is a complex multifactorial disease characterized by an immune and inflammatory process that affects the lacrimal glands and ocular surface [113]. TRPV1 is implicated as a possible drug target since TRPV1 activation hastens corneal epithelial wound healing whereas its inhibition reduces stromal opacification and hypertonicinduced inflammation [80, 114, 115]. TRPM8 activation on afferent sensory corneal nerves and in the different 


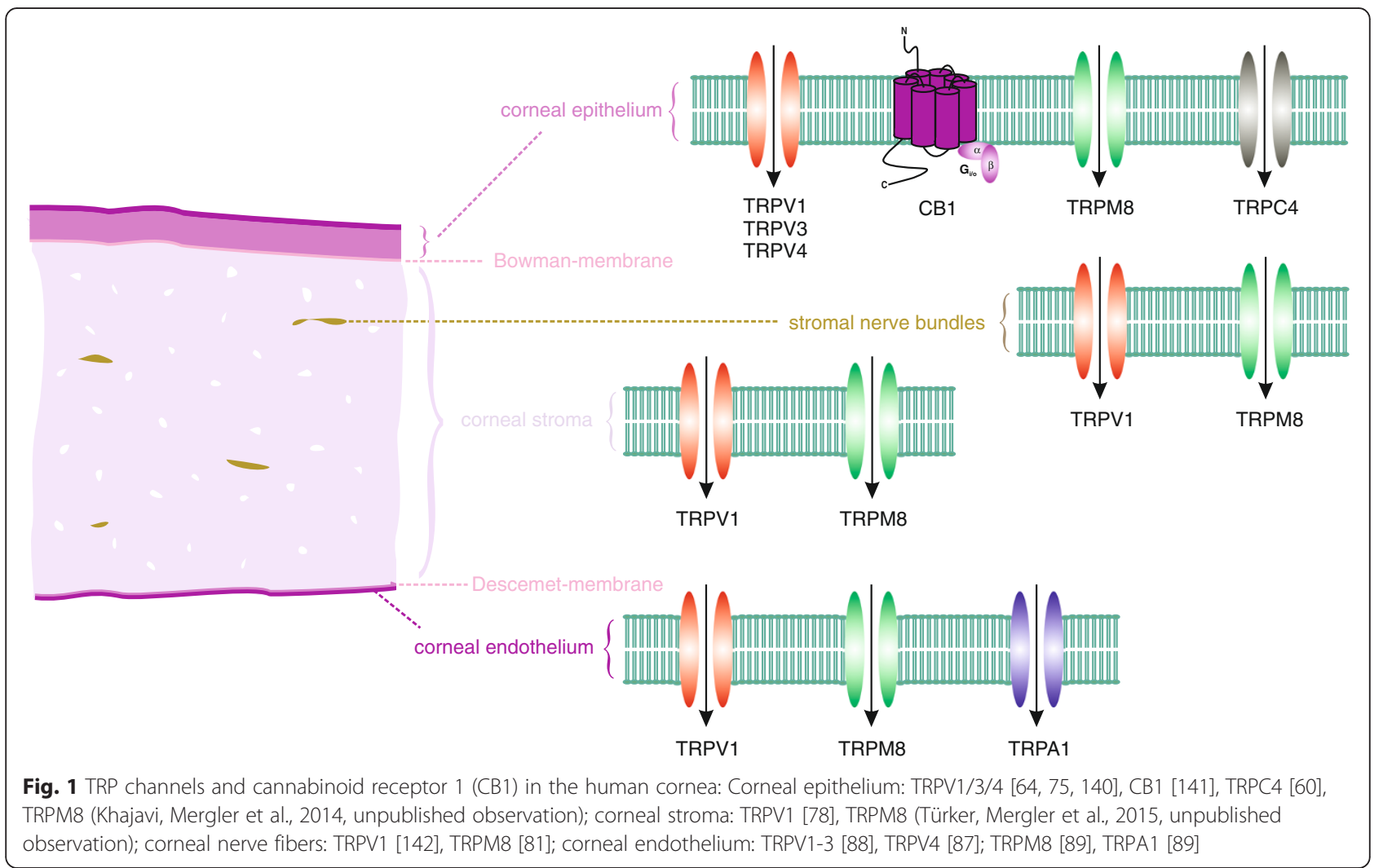

corneal cell types enhances basal tear flow during a decline in ambient temperature $[81,95,115]$.

\section{Diabetic retinopathy}

Ocular diseases such as diabetic retinopathy can be a manifestation of systemic diabetes mellitus. One of its pathophysiological alterations is impaired retinal blood flow due to vascular occlusion. This condition can cause photoreceptor and neuronal hypoxia leading to cell death and visual impairment. Whereas there are various studies describing a connection between TRPs and diabetes mellitus (review [116, 117]), there are no studies directly related to diabetic retinopathy. On the other hand, some are available pertaining to nondiabetic related retinopathy (e.g. melanoma-associated retinopathy) $[112,118,119]$.

\section{Glaucoma}

In glaucoma, one of its pathological effects can includes declines in retinal ganglion cell (RGC) function due to intraocular pressure elevations compressing nerve fibers traversing through the optic nerve head. Changes in TRP function may contribute to changes in RGC function induced by such stress $[49,120]$. Other tissue changes that may contribute to glaucoma damage are obstruction of aqueous outflow pathways through the trabecular meshwork and/or a change in ciliary muscle contractility. As some mechanosensitive TRPC channel subtypes are expressed in these tissues [121], a change in their store-operated channel activity could contribute to trabecular meshwork (TM) pathology [76]. Functional mechanosensitive TRPV4 expression on primary cilia in TM cells transduces pressure changes resulting from variations in aqueous humor formation. This subtype is implicated in how the eye senses such variations to maintain normostensive aqueous humor outflow Its regulatory role suggests that TRPV4 is an attractive therapeutic target for the treatment of hypertensive glaucoma [121]. In another study, TRPC6 gene expression in primary open-angle glaucoma patient leukocytes was detected. Interestingly, its expression was higher than that in control cataract patients, which suggests this channel subtype is a relevant biomarker for this kind of eye disease [122]. Additionally, changes in TRPC6 gene expression level were also correlated with alterations of intraocular pressure and cup-to-disc ratio. However, treatment with different anti-glaucoma drugs did not affect its gene expression. This negative effect illustrates the complexities involved in understanding the pathophysiology of glaucoma.

\section{Ocular tumors}

Ocular tumor development is a rare occurrence compared to its prevalence in non-ocular tissues. In choroidal- or 
corneal neovascularization, this process is not directly related to tumor neovascularization. Nevertheless, neovascularization is a dangerous process whose progression determines tumor growth and metastasis. Endothelial cells (ECs) play a role in neovascularization and several different TRP subtypes have been detected in this tissue (review [123]). At this point, $\mathrm{Ca}^{2+}$ channel drug targeting is being considered in non-ocular tissues (review [124, 125]) and ocular tissues, but findings in these studies are unrelated to tumor neovascularization. One study showed that blockage of $\mathrm{Ca}^{2+}$ activated $\mathrm{K}^{+}$channels inhibited angiogenesis induced by epidermal growth factor (EGF) [126]. In retinal pigment epithelium (RPE), activation of L-type $\mathrm{Ca}^{2+}$ channels is associated with increases in vascular endothelial growth factor (VEGF) secretion. Additionally, basic fibroblast growth factor (bFGF) increased L-type channel activity [127, 128]. A follow-up study demonstrated in the RPE that TRPV2 channels mediate increases in both heat-dependent and IGF-1 (via PI3-kinase activation)-induced VEGF secretion through rises in intracellular $\mathrm{Ca}^{2+}$ levels.

\section{Uveal melanoma}

Uveal melanoma (UM) is a devastating disease in which patient survival rates are poor once this tumor metastasizes out of the eye into the liver, lung, bone and skin. It is the second most prevalent malignant tumor of melanocytes $[129,130]$. This disease directly develops from degenerated melanocytes in the choroid. TRPs expression was identified in healthy non-ocular and ocular melanocytes
[131]. Specifically, TRPM1 was designated as a melanoma metastasis suppressor based on its expression in normal pigment cells in the skin and its absence in aggressive ocular metastatic -competent melanomas. A similar association pertains to TRPA1 because its expression is lower in human uveal melanoma cells than in healthy uvea [59]. An inverse relationship was described for TRPM8 which is expressed at higher levels in most of the investigated UM cell lines [59]. Furthermore, TRPV1 and the cannabinoid receptor $1(\mathrm{CB} 1)$ are functionally expressed in UM cells. Interestingly, activation of $\mathrm{CB} 1$ induced $\mathrm{Ca}^{2+}$ transients, which were suppressed by either $\mathrm{La}^{3+}$ a non-selective TRP channel blocker and capsazepine, a selective TRPV1 antagonist. On the other hand, capsaicin-induced $\mathrm{Ca}^{2+}$ transients could also be suppressed by CB1 activation. Therefore, it is suggested that identification of functional TRPV1, TRPM8, TRPA1 and CB1 expression in uveal melanoma may provide novel drug targets for treatment of this aggressive neoplastic disease [59]. A similar suggestion was made for treating non-uveal melanoma (TRPM8) [132].

\section{Retinoblastoma}

Figure 2 provides an illustrative representation of the different TRP subtypes expressed in the retina. Retinoblastoma (RB) is a malignant retinal tumor, which develops from immature retinal cells. Its incidence is low, but is the most common ocular tumor of the eye in children and is associated with a RB mutation [133]. There are several established cell lines that serve as retinoblastoma cell models exhibiting voltage-dependent ion channel

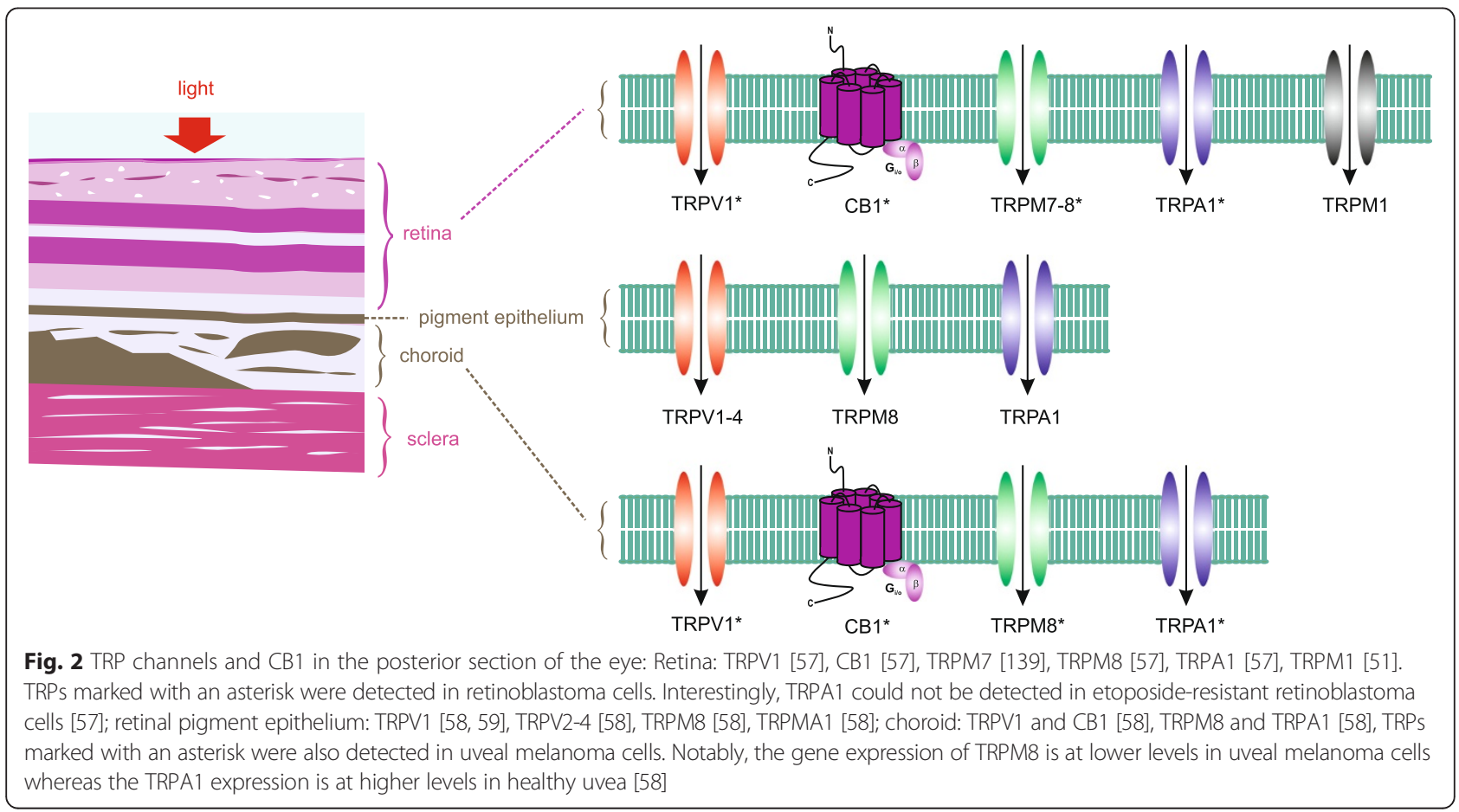


activity [134-138]. Specifically, the $\mathrm{Ca}^{2+}$ channel antagonist mibefradil inhibited cell proliferation via different cytotoxic pathways mediated by voltage-dependent $\mathrm{T}$-type $\mathrm{Ca}^{2+}$ channels [136]. Regarding $\mathrm{Ca}^{2+}$ permeable TRPs, Hanano et al. suggested a possible significant regulatory role of TRPM7 for retinoblastoma cell proliferation as a spontaneously activated $\mathrm{Ca}^{2+}$ influx pathway [139]. Another study revealed TRPV1, TRPM8 and TRPA1 gene expression in retinoblastmoa cells [57]. Notably, the expression of TRPA1 was suppressed in etoposide-resistant RB cells. Therefore, using genetic approaches to upregulate TRPA1 expression could provide a means to induce etoposide sensitivity and suppress RB cell tumorigenesis. Furthermore, CB1 was detected in uveal melanoma cells. Activation of CB1 suppressed TRPV1-induced $\mathrm{Ca}^{2+}$ increases in etoposidesensitive RB cells whereas this effect did not occur in etoposide-resistant RB cells [57]. There have been only a few reports describing a TRP involvement whereas other types of $\mathrm{Ca}^{2+}$ channels have been studied more extensively. Nevertheless, the limited TRP characterizations suggest that there are clear differences between healthy and tumorous ocular tissues or cytostatic-resistant ocular tissue. Therefore, modulation of TRP expression and/or function could provide a badly needed therapeutic option. In addition, monitoring TRP expression levels could provide a prognostic marker for identifying this insidious disease.

\section{Conclusion}

Ocular TRP functional expression is essential for mediating both adaptive and maladaptive responses to a wide variety of environmental stressors challenging tissue homeostasis. Table 1 lists ocular tissue TRP subtype localization and pharmacology described in pertinent references. It is still uncertain how the activation of a

Table 1 Characterization of TRP channel tissue localization

\begin{tabular}{|c|c|c|c|c|c|c|}
\hline Name & $\begin{array}{l}\text { Selectivity } \\
P_{\mathrm{Ca}} \cdot P_{\mathrm{Na}}[12]\end{array}$ & $\begin{array}{l}\text { Activation threshold } \\
\text { temperature }\left({ }^{\circ} \mathrm{C}\right)[30]\end{array}$ & $\begin{array}{l}\text { Pharmacology } \\
{[5,42,143]}\end{array}$ & Function $[5,30]$ & Posterior eye section & Anterior eye section \\
\hline TRPC1 & Non-selective & --- & $\begin{array}{l}\text { Store depletion, } \\
2-A P B\end{array}$ & Component of SOC & Mouse retina $[47,48]$ & HCEC [60], TM [121] \\
\hline TRPC2 & 2.7 & --- & DAG & $?$ & Mouse retina $[47,48]$ & $\mathrm{TM}[121]$ \\
\hline TRPC3 & 1.6 & --- & $\begin{array}{l}\text { Store depletion, OAG, } \\
\text { 2-APB, DAG, Pyr3 }\end{array}$ & Component of SOC & Mouse retina $[47,48]$ & HCEC [60], TM [121] \\
\hline TRPC4 & $1.1-9.0$ & --- & $\begin{array}{l}\text { Store depletion } \\
2-A P B\end{array}$ & Component of SOC & Mouse retina $[47,48]$ & HCEC [60] \\
\hline TRPV1 & $4-10$ & $>43$ & $\begin{array}{l}\text { Capsaicin, capsazepine, } \\
\text { anandamide, NADA }\end{array}$ & $\begin{array}{l}\text { Heat sensor } \\
\text { osmosensor }^{a}\end{array}$ & $\begin{array}{l}\text { Rat retina [49], human } \\
\text { retina (tumor) [57], } \\
\text { uvea (tumor) [59], } \\
\text { human RPE }[58,59]\end{array}$ & $\begin{array}{l}\mathrm{HCEC}[63,64], \mathrm{HCK} \\
{[78], \mathrm{HCEC}-12[88]}\end{array}$ \\
\hline TRPV2 & $1-3$ & $>52$ & Cannabidiol, 2-APB & Heat sensor & Human RPE [58] & HCEC-12 [88] \\
\hline TRPV3 & 2,6 & $30-39$ & Camphor, 2-APB & $\begin{array}{l}\text { Moderate heat } \\
\text { sensor }\end{array}$ & Human RPE [58] & $\begin{array}{l}\text { HCEC [144], } \\
\text { HCEC-12 [88] }\end{array}$ \\
\hline TRPV4 & $6-10$ & $24-27$ & $\begin{array}{l}\text { 4a-PDD, GSK } \\
1016790 A\end{array}$ & $\begin{array}{l}\text { Moderate heat } \\
\text { sensor osmosensor }^{b}\end{array}$ & $\begin{array}{l}\text { Mouse RGC [48], } \\
\text { human RPE [58] }\end{array}$ & $\begin{array}{l}\text { HCEC [75], } \\
\text { HCEC-12 [87], HLE [94] }\end{array}$ \\
\hline TRPM1 & Not determed & --- & mGluR6 & $\begin{array}{l}\text { Transduction of light } \\
\text { signals }\end{array}$ & $\begin{array}{l}\text { Mouse retina }[47,48,145] \text {, } \\
\text { human retina }[51]\end{array}$ & --- \\
\hline TRPM2 & $0.5-1.6$ & & $\begin{array}{l}\mathrm{H}_{2} \mathrm{O}_{2}, \text { ADP-ribose, } \\
\beta-\mathrm{NAD}^{+}\end{array}$ & Mechanotransduction & --- & $\begin{array}{l}\text { HCEC-12 [28], } \\
\text { TM [121] }\end{array}$ \\
\hline TRPM7 & 3 & --- & Spermine & & $\begin{array}{l}\text { Mouse retina }[47,48] \text {, } \\
\text { human retina }[139]\end{array}$ & --- \\
\hline TRPM8 & $1-3.3$ & $<23-28$ & $\begin{array}{l}\text { Menthol, icilin, } \\
\text { eucalyptol, BCTC }\end{array}$ & Moderate cold sensor & $\begin{array}{l}\text { Human retina (tumor) [57], } \\
\text { uvea (tumor) [59] }\end{array}$ & $\begin{array}{l}\operatorname{HCEC}^{C} H C N F[81] \\
\operatorname{HCK}^{c}, \operatorname{HCEC}-12[28,89]\end{array}$ \\
\hline TRPA 1 & 0,8 & $<17$ & Icilin, alicin & Cold sensor & $\begin{array}{l}\text { Human retina (tumor) [57], } \\
\text { uvea [59] }\end{array}$ & $\begin{array}{l}\operatorname{HCEC}-12[28,89] \\
\operatorname{TM}[121]\end{array}$ \\
\hline
\end{tabular}

HCEC human corneal epithelium $H C K$ human corneal keratocytes (stroma) HCEC-12 human corneal endothelium $T M$ trabecular meshwork HCNF human corneal nerve fibers HLE human lens epithelium $R P E$ retinal pigment epithelium $R G C$ retinal ganglion cells activation by hypertonic challenge bactivation by hypotonic challenge 'Mergler et al. 2015 (unpublished data) 
single TRP subtype by diverse stimuli can mediate a number of different signaling pathways and diverse responses. One tenable explanation is that TRP subtypes can have specific molecular determinants with which activators interact. In other words, it still needs to be understood whether there are specific determinants on a TRP subtype that induce each of the different responses attributable to its activation. Each of these different sites may be linked to diverse signaling pathways mediating variety of different responses. Verification of this possibility requires generating site specific TRP mutants to determine if such alterations correspond with any of the pathophysiological responses by cells expressing TRPs. One example of such an approach would entail delineating why capsazepine interaction with TRPV1 in one setting suppresses injury-induced inflammation, but in another setting it instead elevates body temperature. Nevertheless, based on the burgeoning number of TRPrelated publications and commitments pharmaceutical companies are making to identify novel lead compounds for future drug development, it is conceivable that ocular disease management may benefit from such endeavors. This appears to be tenable since there are indications that there is an association between aberrant TRP expression and disease. In any case, much effort must still be committed to determine if there is a cause and effect relationship between specific TRP malfunctions and a pathophysiological condition underlying a eye disease.

\section{Abbreviations \\ TRPs: Transient receptor potential ion channels; $\left[\mathrm{Ca}^{2+}\right]_{i}$ : Intracellular $\mathrm{Ca}^{2+}$ concentration.}

\section{Competing interests}

The authors declare that they have no competing interests.

\section{Authors' contributions}

PSR contributed to the conception, design and drafting of this review. SM contributed to the conception, design and drafting of this review and created the figures as well as the table. YO and SS contributed to the conception of this review. All authors read and approved the final manuscript.

\section{Acknowledgements}

Peter S. Reinach (PhD) is supported by the Zhejiang provincial government. Stefan Mergler (PhD) is supported by DFG (Me 1706/13-1, Me 1706/14-1 and Me1706/18-1) concerning TRP channel related research projects. The authors appreciate the helpful assistance by Noushafarin Khajavi (PhD) (Charité University Berlin, Germany, Eye Clinic).

\section{Declaration}

Publication costs for this article were funded by Department of Ophthalmology, Wakayama Medical University, Wakayama, Japan. This article has been published as part of BMC Ophthalmology Volume 15 Supplement 1, 2015: Proceedings of the 2nd Ocular Cell Biology Symposium at Wakayama. The full contents of the supplement are available online at http://www.biomedcentral.com/bmcophthalmol/supplements.

\footnotetext{
Author details

${ }^{1}$ Department of Ophthalmology and Optometry, Wenzhou Medical University, 270 Xuejuan Road, Wenzhou, Zhejiang 325027, P. R. China. ${ }^{2}$ Department of Ophthalmology, Charité-University Medicine Berlin, Campus Virchow-Clinic, Augustenburger Platz 1, 13353 Berlin, Germany. ${ }^{3}$ Department
}

of Ophthalmology, Wakayama Medical University School of Medicine, Wakayama, Japan.

Published: 17 December 2015

\section{References}

1. Minke B. The history of the Drosophila TRP channel: the birth of a new channel superfamily. J Neurogenet. 2010;24:216-33.

2. Hardie RC, Minke B. The trp gene is essential for a light-activated Ca2+ channel in Drosophila photoreceptors. Neuron. 1992:8:643-51.

3. Cosens DJ, Manning A. Abnormal electroretinogram from a Drosophila mutant. Nature. 1969;224:285-7.

4. Montell C, Rubin GM. Molecular characterization of the Drosophila trp locus: a putative integral membrane protein required for phototransduction. Neuron. 1989:2:1313-23.

5. Ramsey IS, Delling M, Clapham DE. An introduction to TRP channels. Annu Rev Physiol. 2006;68:619-47.

6. Nilius B, Voets T, Peters J. TRP channels in disease. Sci STKE. 2005;2005:re8.

7. Clapham DE, Julius D, Montell C, Schultz G. International Union of Pharmacology. XLIX. Nomenclature and structure-function relationships of transient receptor potential channels. Pharmacol Rev. 2005;57:427-50.

8. O'Neil RG, Heller S. The mechanosensitive nature of TRPV channels. Pflugers Arch. 2005;451:193-203.

9. Plant TD, Strotmann R. TRPV4. Handb Exp Pharmacol. 2007;(179):189-205.

10. Wu L, Gao X, Brown RC, Heller S, O'Neil RG. Dual role of the TRPV4 channel as a sensor of flow and osmolality in renal epithelial cells. Am J Physiol Renal Physiol. 2007;293:F1699-713.

11. Nilius B, Owsianik G. Channelopathies converge on TRPV4. Nat Genet. 2010;42:98-100.

12. Nilius B, Owsianik G, Voets T, Peters JA. Transient receptor potential cation channels in disease. Physiol Rev. 2007;87:165-217.

13. Nilius B, Owsianik G. Transient receptor potential channelopathies. Pflugers Arch. 2010;460:437-50.

14. Schonherr R. Clinical relevance of ion channels for diagnosis and therapy of cancer. J Membr Biol. 2005;205:175-84.

15. Montell C. Physiology, phylogeny, and functions of the TRP superfamily of cation channels. Sci STKE. 2001;2001:RE1.

16. Montell C. The TRP superfamily of cation channels. Sci STKE. 2005;2005:re3.

17. Nilius B, Voets T. TRP channels: a TR(I)P through a world of multifunctional cation channels. Pflugers Archive. 2005;451:1-10.

18. Pedersen SF, Owsianik G, Nilius B. TRP channels: an overview. Cell Calcium. 2005;38:233-52.

19. Harteneck C. Function and pharmacology of TRPM cation channels. Naunyn Schmiedebergs Arch Pharmacol. 2005;371:307-14.

20. Kraft $R$, Harteneck $C$. The mammalian melastatin-related transient receptor potential cation channels: an overview. Pflugers Archive. 2005;451:204-11.

21. Venkatachalam K, Montell C. TRP channels. Annu Rev Biochem. 2007;76:387-417.

22. Christensen AP, Corey DP. TRP channels in mechanosensation: direct or indirect activation? Nat Rev Neurosci. 2007;8:510-21.

23. Chyb S, Raghu P, Hardie RC. Polyunsaturated fatty acids activate the Drosophila light-sensitive channels TRP and TRPL. Nature. 1999;397:255-9.

24. Philipp S, Cavalie A, Freichel M, Wissenbach U, Zimmer S, Trost C, et al. A mammalian capacitative calcium entry channel homologous to Drosophila TRP and TRPL. EMBO J. 1996;15:6166-71.

25. Yoon J, Ben-Ami HC, Hong YS, Park S, Strong LL, Bowman J, et al. Novel mechanism of massive photoreceptor degeneration caused by mutations in the trp gene of Drosophila. J Neurosci. 2000;20:649-59.

26. Mergler S, Pleyer U. The human corneal endothelium: New insights into electrophysiology and ion channels. Prog Retin Eye Res. 2007;26:359-78.

27. Mergler S, Dannowski H, Bednarz J, Engelmann K, Hartmann C, Pleyer U. Calcium influx induced by activation of receptor tyrosine kinases in SV40-transfected human corneal endothelial cells. Exp Eye Res. 2003;77:485-95

28. Mergler S, Pleyer U, Reinach P, Bednarz J, Dannowski H, Engelmann K, et al. EGF suppresses hydrogen peroxide induced $\mathrm{Ca} 2+$ influx by inhibiting L-type channel activity in cultured human corneal endothelial cells. Exp Eye Res. 2005;80:285-93.

29. Li QJ, Ashraf MF, Shen DF, Green WR, Stark WJ, Chan CC, et al. The role of apoptosis in the pathogenesis of Fuchs endothelial dystrophy of the cornea. Arch Ophthalmol. 2001;119:1597-604.

30. Tominaga M, Caterina MJ. Thermosensation and pain. J Neurobiol. 2004;61:3-12. 
31. Voets T, Droogmans G, Wissenbach U, Janssens A, Flockerzi V, Nilius B. The principle of temperature-dependent gating in cold- and heat-sensitive TRP channels. Nature. 2004;430:748-54.

32. Zhong L, Bellemer A, Yan H, Ken H, Jessica R, Hwang RY, et al. Thermosensory and nonthermosensory isoforms of Drosophila melanogaster TRPA1 reveal heat-sensor domains of a thermoTRP Channel. Cell Rep. 2012;1:43-55.

33. Caterina MJ, Schumacher MA, Tominaga M, Rosen TA, Levine JD, Julius D. The capsaicin receptor: a heat-activated ion channel in the pain pathway. Nature. 1997;389:816-24.

34. McKemy DD, Neuhausser WM, Julius D. Identification of a cold receptor reveals a general role for TRP channels in thermosensation. Nature. 2002;416:52-8

35. Moqrich A, Hwang SW, Earley TJ, Petrus MJ, Murray AN, Spencer KS, et al. Impaired thermosensation in mice lacking TRPV3, a heat and camphor sensor in the skin. Science. 2005;307:1468-72.

36. Sherkheli MA, Vogt-Eisele AK, Weber K, Hatt H. Camphor modulates TRPV3 cation channels activity by interacting with critical pore-region cysteine residues. Pak J Pharm Sci. 2013;26:431-8.

37. Ross RA. Anandamide and vanilloid TRPV1 receptors. Br J Pharmacol. 2003;140:790-801.

38. Voets T, Nilius B, Hoefs S, van der Kemp AW, Droogmans G, Bindels RJ, et al. TRPM6 forms the Mg2+ influx channel involved in intestinal and renal Mg2+ absorption. J Biol Chem. 2004;279:19-25.

39. Zurborg S, Yurgionas B, Jira JA, Caspani O, Heppenstall PA. Direct activation of the ion channel TRPA1 by Ca2+. Nat Neurosci. 2007;10:277-9.

40. Devary O, Heichal O, Blumenfeld A, Cassel D, Suss E, Barash S, et al. Coupling of photoexcited rhodopsin to inositol phospholipid hydrolysis in fly photoreceptors. Proc Natl Acad Sci U S A. 1987;84:6939-43.

41. Tiruppathi C, Minshall RD, Paria BC, Vogel SM, Malik AB. Role of Ca2+ signaling in the regulation of endothelial permeability. Vascul Pharmacol. 2002;39:173-85.

42. Harteneck C, Gollasch M. Pharmacological modulation of diacylglycerolsensitive TRPC3/6/7 channels. Curr Pharm Biotechnol. 2011;12:35-41.

43. Liu B, Qin F. Functional control of cold- and menthol-sensitive TRPM8 ion channels by phosphatidylinositol 4,5-bisphosphate. J Neurosci. 2005:25:1674-81.

44. Otsuguro K, Tang J, Tang Y, Xiao R, Freichel M, Tsvilovskyy V, et al. Isoformspecific inhibition of TRPC4 channel by phosphatidylinositol 4,5-bisphosphate. J Biol Chem. 2008;283:10026-36.

45. Pak WL. Drosophila in vision research. The Friedenwald Lecture. Invest Ophthalmol Vis Sci, 1995;36:2340-57.

46. Montell C. Drosophila visual transduction. Trends Neurosci. 2012;35:356-63.

47. Gilliam JC, Wensel TG. TRP channel gene expression in the mouse retina. Vision Res. 2011;51:2440-52.

48. Ryskamp DA, Witkovsky P, Barabas P, Huang W, Koehler C, Akimov NP, et al The polymodal ion channel transient receptor potential vanilloid 4 modulates calcium flux, spiking rate, and apoptosis of mouse retinal ganglion cells. J Neurosci. 2011:31:7089-101.

49. Sappington RM, Sidorova T, Long DJ, Calkins D. TRPV1: Contribution to Retinal Ganglion Cell Apoptosis and Increased Intracellular Ca2+ with Exposure to Hydrostatic Pressure. Invest Ophthalmol Vis Sci. 2009;50:717-28.

50. Crousillac S, LeRouge M, Rankin M, Gleason E. Immunolocalization of TRPC channel subunits 1 and 4 in the chicken retina. Vis Neurosci. 2003;20:453-63.

51. Klooster J, Blokker J, Ten Brink JB, Unmehopa U, Fluiter K, Bergen AA, et al. Ultrastructural localization and expression of TRPM1 in the human retina. Invest Ophthalmol Vis Sci. 2011;52:8356-62.

52. Morgans CW, Zhang J, Jeffrey BG, Nelson SM, Burke NS, Duvoisin RM, et al. TRPM1 is required for the depolarizing light response in retinal ON-bipolar cells. Proc Natl Acad Sci U S A. 2009;106:19174-8.

53. Audo I, Bujakowska K, Orhan E, Poloschek CM, Defoort-Dhellemmes S, Drumare I, et al. Whole-exome sequencing identifies mutations in GPR179 leading to autosomal-recessive complete congenital stationary night blindness. Am J Hum Genet. 2012;90:321-30.

54. Shen Y, Rampino MA, Carroll RC, Nawy S. G-protein-mediated inhibition of the Trp channel TRPM1 requires the Gbetagamma dimer. Proc Natl Acad Sci U S A. 2012;109:8752-7.

55. Dhingra A, Ramakrishnan $H$, Neinstein A, Fina ME, Xu Y, Li J, et al. Gbeta3 is required for normal light $\mathrm{ON}$ responses and synaptic maintenance. J Neurosci. 2012;32:11343-55.

56. Devi S, Markandeya Y, Maddodi N, Dhingra A, Vardi N, Balijepalli RC, et al. Metabotropic glutamate receptor 6 signaling enhances TRPM1 calcium channel function and increases melanin content in human melanocytes. Pigment Cell Melanoma Res. 2013;26(3):348-56.

57. Mergler S, Cheng Y, Skosyrsky S, Garreis F, Pietrzak P, Kociok N, et al. Altered calcium regulation by thermo-sensitive transient receptor potential channels in etoposide-resistant WERI-Rb1 retinoblastoma cells. Exp Eye Res. 2012;94:157-73.

58. Cordeiro S, Seyler S, Stindl J, Milenkovic VM, Strauss O. Heat-sensitive TRPV channels in retinal pigment epithelial cells: regulation of VEGF-A secretion. Invest Ophthalmol Vis Sci. 2010;51:6001-8.

59. Mergler S, Derckx R, Reinach PS, Garreis F, Bohm A, Schmelzer L, et al. Calcium regulation by temperature-sensitive transient receptor potential channels in human uveal melanoma cells. Cell Signal. 2013;26:56-69.

60. Yang H, Mergler S, Sun X, Wang Z, Lu L, Bonanno JA, et al. TRPC4 knockdown suppresses EGF-induced store operated channel activation and growth in human corneal epithelial cells. J Biol Chem. 2005;280:32230-7.

61. Yang H, Wang Z, Capo-Aponte JE, Zhang F, Pan Z, Reinach PS. Epidermal growth factor receptor transactivation by the cannabinoid receptor (CB1) and transient receptor potential vanilloid 1 (TRPV1) induces differential responses in corneal epithelial cells. Exp Eye Res. 2010;91:462-71.

62. Sumioka T, Okada Y, Reinach PS, Shirai K, Miyajima M, Yamanaka O, et al. Impairment of cornea epithelial wound healing in a TRPV1-deficient mouse. Invest Ophthalmol Vis Sci 2014, (in press).

63. Zhang F, Yang H, Wang Z, Mergler S, Liu H, Kawakita T, et al. Transient receptor potential vanilloid 1 activation induces inflammatory cytokine release in corneal epithelium through MAPK signaling. J Cell Physiol. 2007;213:730-9.

64. Mergler S, Garreis F, Sahlmuller M, Reinach PS, Paulsen F, Pleyer U. Thermosensitive transient receptor potential channels in human corneal epithelial cells. J Cell Physiol. 2011;226:1828-42.

65. Becker D, Blase C, Bereiter-Hahn J, Jendrach M. TRPV4 exhibits a functional role in cell-volume regulation. J Cell Sci. 2005;118:2435-40.

66. Fian R, Grasser E, Treiber F, Schmidt R, Niederl P, Rosker C. The contribution of TRPV4-mediated calcium signaling to calcium homeostasis in endothelial cells. J Recept Signal Transduct Res. 2007;27:113-24.

67. Liedtke W. TRPV4 as osmosensor: a transgenic approach. Pflugers Arch. 2005;451:176-80.

68. Vos MH, Neelands TR, McDonald HA, Choi W, Kroeger PE, Puttfarcken PS, et al. TRPV1b overexpression negatively regulates TRPV1 responsiveness to capsaicin heat and low pH in HEK293 cells. J Neurochem. 2006;99:1088-102.

69. Leffler A, Linte RM, Nau C, Reeh P, Babes A. A high-threshold heat-activated channel in cultured rat dorsal root ganglion neurons resembles TRPV2 and is blocked by gadolinium. Eur J Neurosci. 2007;26:12-22.

70. Chung MK, Lee H, Mizuno A, Suzuki M, Caterina MJ. 2-aminoethoxydiphenyl borate activates and sensitizes the heat-gated ion channel TRPV3. J Neurosci. 2004;24:5177-82.

71. Guler AD, Lee H, lida T, Shimizu I, Tominaga M, Caterina M. Heat-evoked activation of the ion channel, TRPV4. J Neurosci. 2002;22:6408-14.

72. Watanabe H, Vriens J, Suh SH, Benham CD, Droogmans G, Nilius B. Heat-evoked activation of TRPV4 channels in a HEK293 cell expression system and in native mouse aorta endothelial cells. J Biol Chem. 2002;277:47044-51.

73. Bautista DM, Siemens J, Glazer JM, Tsuruda PR, Basbaum Al, Stucky CL, et al. The menthol receptor TRPM8 is the principal detector of environmental cold. Nature. 2007:448:204-8.

74. McKemy DD. How cold is it? TRPM 8 and TRPA1 in the molecular logic of cold sensation. Mol Pain. 2005;1:16.

75. Pan Z, Yang H, Mergler S, Liu H, Tachado SD, Zhang F, et al. Dependence of regulatory volume decrease on transient receptor potential vanilloid 4 (TRPV4) expression in human corneal epithelial cells. Cell Calcium. 2008;44:374-85.

76. Pan Z, Yang H, Reinach PS. Transient receptor potential (TRP) gene superfamily encoding cation channels. Hum Genomics. 2011;5:108-16.

77. Pan Z, Wang Z, Yang H, Zhang F, Reinach PS. TRPV1 Activation is Required for Hypertonicity Stimulated Inflammatory Cytokine Release in Human Corneal Epithelial Cells. Invest Ophthalmol Vis Sci 2010. (Epub ahead of print).

78. Yang Y, Yang H, Wang Z, Mergler S, Wolosin JM, Reinach PS. Functional TRPV1 expression in human corneal fibroblasts. Exp Eye Res. 2013;107:121-9.

79. Yang Y, Wang Z, Yang H, Wang L, Gillespie SR, Wolosin JM, et al. TRPV1 potentiates TGFbeta-induction of corneal myofibroblast development through an oxidative stress-mediated p38-SMAD2 signaling loop. PLOS ONE. 2013;8:e77300. 
80. Okada Y, Reinach PS, Shirai K, Kitano A, Kao WW, Flanders KC, et al. TRPV1 Involvement in Inflammatory Tissue Fibrosis in Mice. Am J Pathol. 2011;178:2654-64.

81. Parra A, Madrid R, Echevarria D. del OS, Morenilla-Palao C, Acosta MC et al. Ocular surface wetness is regulated by TRPM8-dependent cold thermoreceptors of the cornea. Nat Med. 2010;16:1396-9.

82. Marfurt CF, Cox J, Deek S, Dvorscak L. Anatomy of the human corneal innervation. Exp Eye Res. 2010;90:478-92.

83. Hirata H, Oshinsky ML. Ocular dryness excites two classes of corneal afferent neurons implicated in basal tearing in rats: involvement of transient receptor potential channels. J Neurophysiol. 2012;107:1199-209.

84. Madrid R, Donovan-Rodriguez T, Meseguer V, Acosta MC, Belmonte C, Viana F. Contribution of TRPM8 channels to cold transduction in primary sensory neurons and peripheral nerve terminals. J Neurosci. 2006;26:12512-25.

85. Robbins A, Kurose M, Winterson BJ, Meng ID. Menthol activation of corneal cool cells induces TRPM8-mediated lacrimation but not nociceptive responses in rodents. Invest Ophthalmol Vis Sci. 2012;53:7034-42.

86. Rae JL, Watsky MA. Ionic channels in corneal endothelium. Am J Physiol. 1996:270:C975-89.

87. Mergler S, Valtink M, Taetz K, Sahlmuller M, Fels G, Reinach PS, et al. Characterization of transient receptor potential vanilloid channel 4 (TRPV4) in human corneal endothelial cells. Exp Eye Res. 2011;93:710-9.

88. Mergler S, Valtink M, Coulson-Thomas VJ, Lindemann D, Reinach PS, Engelmann K, et al. TRPV channels mediate temperature-sensing in human corneal endothelial cells. Exp Eye Res. 2010;90:758-70.

89. Mergler S, Mertens C, Valtink M, Reinach PS, Szekely VC, Slavi N, et al. Functional significance of thermosensitive transient receptor potential melastatin channel 8 (TRPM8) expression in immortalized human corneal endothelial cells. Exp Eye Res. 2013;116:337-49.

90. Hsu JK, Cavanagh HD, Jester JV, Ma L, Petroll WM. Changes in corneal endothelial apical junctional protein organization after corneal cold storage. Cornea. 1999;18:712-20.

91. Lindstrom RL. Advances in corneal preservation. Trans Am Ophthalmol Soc. 1990;88:555-648.

92. Sandboe FD, Medin W, Froslie KF. Influence of temperature on corneas stored in culture medium. A comparative study using functional and morphological methods. Acta Ophthalmol Scand. 2003;81:54-9.

93. Bennett TM, Mackay DS, Siegfried CJ, Shiels A. Mutation of the melastatin-related cation channel, TRPM3, underlies inherited cataract and glaucoma. PLoS ONE. 2014;9:e104000.

94. Shahidullah M, Mandal A, Delamere NA. TRPV4 in porcine lens epithelium regulates hemichannel-mediated ATP release and Na-K-ATPase activity. Am J Physiol Cell Physiol. 2012;302:C1751-61.

95. Mergler S, Garreis F, Sahlmuller M, Lyras EM, Reinach PS, Dwarakanath A, et al. Calcium regulation by thermo- and osmosensing transient receptor potential vanilloid channels (TRPVs) in human conjunctival epithelial cells. Histochem Cell Biol. 2012;137:743-61.

96. Khajavi N, Reinach PS, Slavi N, Skrzypski M, Lucius A, Strauss O, et al. Thyronamine induces TRPM8 channel activation in human conjunctival epithelial cells. Cell Signal. 2015;27:315-25.

97. Lang F, Foller M, Lang KS, Lang PA, Ritter M, Gulbins E, et al. lon channels in cell proliferation and apoptotic cell death. J Membr Biol. 2005;205:147-57.

98. Casas S, Novials A, Reimann F, Gomis R, Gribble FM. Calcium elevation in mouse pancreatic beta cells evoked by extracellular human islet amyloid polypeptide involves activation of the mechanosensitive ion channel TRPV4. Diabetologia. 2008;51:2252-62.

99. Chow J, Norng M, Zhang J, Chai J. TRPV6 mediates capsaicin-induced apoptosis in gastric cancer cells-Mechanisms behind a possible new "hot" cancer treatment. Biochim Biophys Acta. 1773;2007:565-76.

100. Sappington RM, Sidorova T, Long DJ, Calkins DJ. TRPV1: Contribution to retinal ganglion apoptosis and intracellular $\mathrm{Ca} 2+$ with exposure to hydrostatic pressure. Invest Ophthalmol Vis Sci. 2009;50:717-28.

101. Satoh S, Tanaka H, Ueda Y, Oyama J, Sugano M, Sumimoto H, et al. Transient receptor potential (TRP) protein 7 acts as a $\mathrm{G}$ protein-activated $\mathrm{Ca} 2+$ channel mediating angiotensin II-induced myocardial apoptosis. Mol Cell Biochem. 2007;294:205-15.

102. Zhang W, Chu X, Tong Q, Cheung JY, Conrad K, Masker K, et al. A novel TRPM2 isoform inhibits calcium influx and susceptibility to cell death. J Biol Chem. 2003;278:16222-9.

103. Orrenius S, Zhivotovsky B, Nicotera P. Regulation of cell death: the calcium-apoptosis link. Nat Rev Mol Cell Biol. 2003;4:552-65.
104. Ward NJ, Ho KW, Lambert WS, Weitlauf C, Calkins DJ. Absence of transient receptor potential vanilloid-1 accelerates stress-induced axonopathy in the optic projection. J Neurosci. 2014;34:3161-70.

105. Gees M, Owsianik G, Nilius B, Voets T. TRP channels. Compr Physiol. 2012;2:563-608.

106. Szallasi A, Cortright DN, Blum CA, Eid SR. The vanilloid receptor TRPV1: 10 years from channel cloning to antagonist proof-of-concept. Nat Rev Drug Discov. 2007;6:357-72.

107. Martinez-Garcia MC, Martinez T, Paneda C, Gallego P, Jimenez Al, Merayo J. Differential expression and localization of transient receptor potential vanilloid 1 in rabbit and human eyes. Histol Histopathol. 2013;28:1507-16.

108. Kaneko Y, Szallasi A. Transient receptor potential (TRP) channels: a clinical perspective. Br J Pharmacol. 2014;171:2474-507.

109. Nilius B. A Special Issue on channelopathies. Pflugers Arch. 2010;460:221-2.

110. Smani T, Shapovalov G, Skryma R, Prevarskaya N, Rosado JA. Functional and physiopathological implications of TRP channels. Biochim Biophys Acta 2015;1853;1772-82.

111. Bach G. Mucolipin 1: endocytosis and cation channel-a review. Pflugers Arch. 2005;451:313-7.

112. Irie S, Furukawa T. Trpm1. Handb Exp Pharmacol. 2014;222:387-402.

113. Barabino S, Dana MR. Dry eye syndromes. Chem Immunol Allergy. 2007;92:176-84.

114. Sumioka T, Okada Y, Reinach PS, Shirai K, Miyajima M, Yamanaka O, et al. Impairment of corneal epithelial wound healing in a TRPV1-deficient mouse. Invest Ophthalmol Vis Sci. 2014;55:3295-302.

115. Pan Z, Wang Z, Yang H, Zhang F, Reinach PS. TRPV1 activation is required for hypertonicity-stimulated inflammatory cytokine release in human corneal epithelial cells. Invest Ophthalmol Vis Sci. 2011;52:485-93.

116. Islam MS. TRP channels of islets. Adv Exp Med Biol. 2011;704:811-30.

117. Jacobson DA, Philipson LH. TRP channels of the pancreatic beta cell. Handb Exp Pharmacol 2007;(179):409-24.

118. Morita Y, Kimura K, Fujitsu Y, Enomoto A, Ueno S, Kondo M, et al. Autoantibodies to transient receptor potential cation channel, subfamily $M$, member 1 in a Japanese patient with melanoma-associated retinopathy. Jpn J Ophthalmol. 2014;58:166-71.

119. Ueno S, Ito Y, Maruko R, Kondo M, Terasaki H. Choroidal atrophy in a patient with paraneoplastic retinopathy and anti-TRPM1 antibody. Clin Ophthalmol. 2014;8:369-73.

120. Krizaj D, Ryskamp D, Tian N, Tezel G, Mitchell CH, Slepak VZ, et al. From mechanosensitivity to inflammatory responses: new players in the pathology of glaucoma. Curr Eye Res. 2014;39:105-19.

121. Tran VT, Ho PT, Cabrera L, Torres JE, Bhattacharya SK. Mechanotransduction channels of the trabecular meshwork. Curr Eye Res. 2014;39:291-303.

122. Chen S, Fan Q, Gao X, Wang X, Huang R, Laties AM, et al. Increased expression of the transient receptor potential cation channel 6 gene in patients with primary open-angle glaucoma. Clin Experiment Ophthalmol. 2013;41:753-60.

123. Fiorio PA, Avanzato D, Munaron L, Ambudkar IS. Ion channels and transporters in cancer. 6. Vascularizing the tumor: TRP channels as molecular targets. Am J Physiol Cell Physiol. 2012;302:C9-15.

124. Munaron L, Genova T, Avanzato D. Antoniotti S. Targeting Calcium Channels to Block Tumor Vascularization. Recent Pat Anticancer Drug Discov: Fiorio PA; 2012.

125. Nilius B, Droogmans G, Wondergem R. Transient receptor potential channels in endothelium: solving the calcium entry puzzle? Endothelium. 2003;10:5-15.

126. Yang H, Li X, Ma J, Lv X, Zhao S, Lang W, et al. Blockade of the intermediate-conductance $\mathrm{Ca}(2+)$-activated $\mathrm{K}+$ channel inhibits the angiogenesis induced by epidermal growth factor in the treatment of corneal alkali burn. Exp Eye Res. 2013;110:76-87.

127. Rosenthal R, Malek G, Salomon N, Peill-Meininghaus M, Coeppicus L, Wohlleben $\mathrm{H}$, et al. The fibroblast growth factor receptors, FGFR-1 and FGFR-2, mediate two independent signalling pathways in human retinal pigment epithelial cells. Biochem Biophys Res Commun. 2005;337:241-7.

128. Rosenthal R, Heimann H, Agostini H, Martin G, Hansen LL, Strauss O. Ca2+ channels in retinal pigment epithelial cells regulate vascular endothelial growth factor secretion rates in health and disease. Mol Vis. 2007;13:443-56.

129. Chang AE, Karnell LH, Menck HR. The National Cancer Data Base report on cutaneous and noncutaneous melanoma: a summary of 84,836 cases from the past decade. The American College of Surgeons Commission on Cancer and the American Cancer Society. Cancer. 1998;83:1664-78. 
130. Singh AD, Turell ME, Topham AK. Uveal melanoma: trends in incidence, treatment, and survival. Ophthalmology. 2011;118:1881-5.

131. Devi S, Kedlaya R, Maddodi N, Bhat KM, Weber CS, Valdivia H, et al. Calcium homeostasis in human melanocytes: role of transient receptor potential melastatin 1 (TRPM1) and its regulation by ultraviolet light. Am J Physiol Cell Physiol. 2009;297:C679-87.

132. Yamamura H, Ugawa S, Ueda T, Morita A, Shimada S. TRPM8 activation suppresses cellular viability in human melanoma. Am J Physiol Cell Physiol. 2008;295:C296-301.

133. Lohmann D. Retinoblastoma. Adv Exp Med Biol. 2010;685:220-7.

134. Barnes S, Haynes LW. Low-voltage-activated calcium channels in human retinoblastoma cells. Brain Res. 1992;598:19-22.

135. Bertolesi GE, Da Walia SR, Jollimore CA, Shi C, Barnes S, Kelly ME. Ca(v)3.1 splice variant expression during neuronal differentiation of $\mathrm{Y}-79$ retinoblastoma cells. Neuroscience. 2006;141:259-68.

136. Bertolesi GE, Shi C, Elbaum L, Jollimore C, Rozenberg G, Barnes S, et al. The $\mathrm{Ca}(2+)$ channel antagonists mibefradil and pimozide inhibit cell growth via different cytotoxic mechanisms. Mol Pharmacol. 2002;62:210-9.

137. del Pilar GM, Waloga G, Nasi E. Induction of voltage-dependent sodium channels by in vitro differentiation of human retinoblastoma cells. J Neurophysiol. 1993;70:1487-96.

138. Hirooka K, Bertolesi GE, Kelly ME, Denovan-Wright EM, Sun X, Hamid J, et al. T-Type calcium channel alpha1G and alpha1H subunits in human retinoblastoma cells and their loss after differentiation. J Neurophysiol. 2002;88:196-205.

139. Hanano T, Hara Y, Shi J, Morita H, Umebayashi C, Mori E, et al. Involvement of TRPM7 in cell growth as a spontaneously activated Ca2+ entry pathway in human retinoblastoma cells. J Pharmacol Sci. 2004;95:403-19.

140. Garreis F, Gottschalt M, Schlorf T, Glaser R, Harder J, Worlitzsch D, et al. Expression and regulation of antimicrobial peptide psoriasin (S100A7) at the ocular surface and in the lacrimal apparatus. Invest Ophthalmol Vis Sci. 2011;52:4914-22.

141. Yang Y, Yang H, Wang Z, Varadaraj K, Kumari SS, Mergler S, et al. Cannabinoid receptor 1 suppresses transient receptor potential vanilloid 1-induced inflammatory responses to corneal injury. Cell Signal. 2013;25:501-11.

142. Murata Y, Masuko S. Peripheral and central distribution of TRPV1, substance P and CGRP of rat corneal neurons. Brain Res. 2006;1085:87-94.

143. Vriens J, Appendino G, Nilius B. Pharmacology of vanilloid transient receptor potential cation channels. Mol Pharmacol. 2009;75:1262-79.

144. Yamada T, Ueda T, Ugawa S, Ishida Y, Imayasu M, Koyama S, et al. Functional expression of transient receptor potential vanilloid 3 (TRPV3) in corneal epithelial cells: involvement in thermosensation and wound healing. Exp Eye Res. 2010;90:121-9.

145. Schmidt TM. Role of melastatin-related transient receptor potential channel TRPM1 in the retina: Clues from horses and mice. J Neurosci. 2009;29:11720-2.

\section{Submit your next manuscript to BioMed Central and take full advantage of:}

- Convenient online submission

- Thorough peer review

- No space constraints or color figure charges

- Immediate publication on acceptance

- Inclusion in PubMed, CAS, Scopus and Google Scholar

- Research which is freely available for redistribution
C Biomed Central 